\title{
The Impact of a Small Games Program on Reducing Some Mental Disorders in the Children of Fractured Families
}

\section{Dr/ Bassant Mohamed Ha problem}

The family is the first group to receive a child from birth, and the primary responsibility for its behavior is the child acquires the behavioral assets, skills, attitudes, and values that grow through them, which depend primarily on the existence of a special and strong relationship between the child and the parent.

The family is defined as a unit of interacting people, in which each person is assigned a number of roles, ie, the individual understands the criteria and expectations of the role that other members of the family determine for him and their behavior (3:74)

And the organic entity prisoners represent the basic social unit in society, and whenever family relations and family cohesion and cohesion between the members of the family is strong, this led to healthy social relations and ties between members in their dealings within the family and in society, on the contrary when the atmosphere of dissonance and conflict within the family and the desire In carrying responsibilities the family collapses (26: 134135)

This relationship includes a special kind of care that is characterized by compassion, love, tenderness and protection, all of which are important functions in the formation of the human personality of the newborn, and acquire its values, habits and methods of behavior, and the behavioral methods that it must adopt as a method of its behavior as the link between the individual and society. : 131) (1: 48) (8:1)

Therefore, we find that proper family formation means creating the right environment for the children within the family 
to satisfy the healthy body, mind and soul and meet their basic needs, and to provide opportunities for them to interact positively with their society. (6: 119) (13: 225.)

The

family

atmosphere affects the satisfaction of children for their main emotional needs. If the child feels the security and tranquility that the family provides for him, this will necessarily appear in his external relationship with the individuals around him. The emotional relationships and interactions between the child and his parents constitute his expectations and subsequent responses. Parents determine the child's behavior and are very similar to one another (5:29) (28: 249)

The family is not just an instrument for transferring the values and social heritage of new generations, but it is also a factor in preventing the child from being influenced by undesirable bad models.

Which has the greatest impact on the weakness

of

communication

between

family members, and the risk is that it leads to what is called family disintegration or family disintegration or family disintegration Family Disorganization, which refers to the unconnected family, which has among its members and their forms severe obstacles that limit the interaction between them or the psychological isolation between the individual and the other as the study of Tannila et al. (34: 81)

Family harmony has a direct impact on the human formation of the individual and the development of his personality, the formation of his concept of himself, the determination of his value, beliefs, trends and tendencies, in addition to providing the methods that are compatible with himself and his environment and depends on his compatibility with himself for his compatibility with his family. And that the family consensus is 
responsible for the origin of ma (26 (25: 195)

that one of the primary objectives of the physical education lesson is to provide the means and supports for the child's integrated development in terms of physical،

The activities of the small games that are concerned with the lesson of physical education are the most common activities and practice by children in and out of the lesson and contribute a significant role in the development of basic motor skills as these skills are the basic rule of motor mobility of the child as the practice and attention to develop is a fundamental pillar of the practice of motor activity (28: 7) (85:17) This is the first time I have been in my life.

Therefore, it is through the work of the researcher in the field of sports psychology, as well as its work in the institution of treatment and behavioral of children has noted a significant correlation between the cracking of prisoners and mental disorders in the children of these fractured families in the province of Gharbia, which seek to try to reach the reality of that relationship, and its impact on the behavior Children By studying the effectiveness of a program using small games to reduce some mental disorders in a sample of children of rift families hope to be a new scientific addition in the field of family relations in particular and the field of sports psychology in general.

\section{Search Goal:}

The present study aims to identify the effect of a small game program on reducing some mental disorders among children of fractured families.

\section{Research hypotheses:}

1-There are statistically significant differences between the averages of tribal and remote measurements in the level of self-concept among the children of the fractured families.

2-There are statistically significant differences between the averages of 
tribal and remote measurements in the anxiety of children of fractured families.

3-There are statistically significant differences between the averages of tribal and remote measurements in the personality tests of children of fractured families.

Search procedures-:

First

"Research

\section{Methodology:}

The researcher used the experimental method using measurements (tribal and remote) using the experimental design of one group to suit the nature of this research.

\section{Community and Sample}

Search:

The research community includes the children of the parents of one of the parents in the schools of Al-Gharbia governorate in Al-Mashaleh Al-Kubra city in the academic year 2017/2018. The size of the society reached fifty-five children between the ages of 12 and 15. The researcher chose a random sample (15) fifteen children "representing $(27.3 \%)$ of the research community.

The mean distribution of the sample was calculated in the variables in question and Table (1)

The result shows:

Table (1)

Arithmetic mean, median, standard deviation, and torsion coefficients for age and variables Psychological research in children $N=15$

\begin{tabular}{|c|c|c|c|c|c|c|}
\hline \multicolumn{3}{|c|}{ Variables } & SMA & Mediator & $\begin{array}{l}\text { standard } \\
\text { deviation }\end{array}$ & $\begin{array}{c}\text { Torsion } \\
\text { coefficient }\end{array}$ \\
\hline \multicolumn{3}{|c|}{ Real Age } & 13.81 & 13.90 & 0.91 & -0.30 \\
\hline \multicolumn{3}{|c|}{ Anxiety Scale } & 135.40 & 136.00 & 3.14 & -0.57 \\
\hline \multicolumn{3}{|c|}{ Self-concept scale for children } & 38.53 & 39.00 & 3.72 & -0.38 \\
\hline \multirow{2}{*}{ 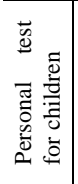 } & \multirow[b]{2}{*}{ 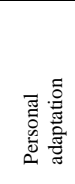 } & $\begin{array}{l}\text { Adopt the } \\
\text { child himself }\end{array}$ & 4.93 & 5.00 & 0.80 & -0.26 \\
\hline & & $\begin{array}{l}\text { The child's } \\
\text { sense of value }\end{array}$ & 4.60 & 5.00 & 1.35 & -0.89 \\
\hline
\end{tabular}


Follow Table (1)

Arithmetic mean, median, standard deviation, and torsion coefficients for age and variables Psychological research in children $N=15$

\begin{tabular}{|c|c|c|c|c|c|}
\hline \multicolumn{2}{|c|}{ Variables } & SMA & Mediator & $\begin{array}{l}\text { standard } \\
\text { deviation }\end{array}$ & $\begin{array}{c}\text { Torsion } \\
\text { coefficicent }\end{array}$ \\
\hline & The child feels free & 4.53 & 4.00 & 1.60 & 0.99 \\
\hline & $\begin{array}{l}\text { The child's sense } \\
\text { of belonging }\end{array}$ & 4.73 & 5.00 & 1.33 & -0.61 \\
\hline & $\begin{array}{l}\text { Freedom from } \\
\text { the tendency to } \\
\text { be alone }\end{array}$ & 5.20 & 5.00 & 1.42 & 0.42 \\
\hline & $\begin{array}{l}\text { Free of neurotic } \\
\text { symptoms }\end{array}$ & 5.07 & 5.00 & 1.10 & 0.19 \\
\hline & Total score & 29.06 & 28.00 & 4.40 & 0.72 \\
\hline & Social levels & 6.00 & 6.00 & 0.85 & 0 \\
\hline & social skills & 5.53 & 5.00 & 1.25 & 1.27 \\
\hline $\overrightarrow{\bar{\theta}}$ & $\begin{array}{l}\text { Freedom from anti- } \\
\text { social tendencies }\end{array}$ & 5.40 & 5.00 & 0.83 & 1.45 \\
\hline 志 & $\begin{array}{l}\text { Relationships } \\
\text { in the family }\end{array}$ & 5.53 & 6.00 & 0.92 & -1.53 \\
\hline$\frac{\tilde{\pi}}{\frac{\pi}{0}}$ & $\begin{array}{l}\text { Relationship } \\
\mathrm{s} \text { in school }\end{array}$ & 5.53 & 6.00 & 0.99 & -1.42 \\
\hline $\mathscr{n}$ & $\begin{array}{l}\text { Relationships } \\
\text { in the local } \\
\text { environment }\end{array}$ & 5.60 & 6.00 & 1.12 & -1.07 \\
\hline & Total score & 33.59 & 33.00 & 2.61 & 0.68 \\
\hline The t & al score of the test & 62.65 & 63.00 & 5.02 & -0.21 \\
\hline
\end{tabular}

Table (1) shows the following:

The values of the convolution coefficients ranged from (1.45: -1.53), ie, they are limited to $(+/-$ 3), indicating the moderation of the

distribution of the sample in these variables.

\section{Data collection tools:}

To collect research data, the researcher used the following tools: 
First:

psychological measures

1-Anxiety Scale Prepared by Abdul Aziz al-Shafi'i (1998)

2-the scale of the concept of self-preparation/ Adel AlAshool (2006)

3-Personality test Preparation/ Attia here (1990)

Second:

Behavioral

Guidance Program

The proposed small games program:

The

researcher

reviewed many scientific references and previous studies related to the field of this research and polled the opinions of many specialized professors so that the components of the program can be determined in proportion to the age of children and in light of their abilities and needs.

Contents of the proposed program for small games:

Distribution of small games in the educational unit

1 -Special mini-games for the development of general fitness elements and taught in the physical preparation part.

r-Small games for the development of social skills and reduce mental disorders in children sample study.

In the selection of small games, the researcher took into account the balance, variety and flexibility of the children according to the physical abilities of these children, and required their exercise to be difficult to achieve the purpose chosen for the game. In order to increase the motivation and excitement to practice, And controlling unwanted behaviors.

$\begin{aligned} & \text { Application of } \\ & \text { program the } \\ & \text { experimental group }\end{aligned}$
to

The researcher

replaced the method used to prepare the general physical and small games that develop the same elements, as well as the replacement of the method used to teach in the main part of small games, taking into account the gradient easy to the difficult and the importance of each skill by explaining the game with the correction of performance, The unit is complete with the use of small games in the physical preparation parts and the main part. 


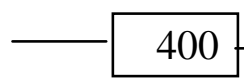

Table (2)

Time distribution of parts

\begin{tabular}{|c|c|c|c|c|c|c|}
\hline \multicolumn{5}{|c|}{ Proposed Psychological unity } & \multicolumn{2}{|c|}{ Games } \\
\hline & & & \multicolumn{2}{|c|}{$\begin{array}{l}\text { The unit time } \\
\text { is } 45 \text { minutes }\end{array}$} & from & to \\
\hline \multirow{4}{*}{\multicolumn{2}{|c|}{$\begin{array}{l}\text { Introductory } \\
\text { part }\end{array}$}} & $\begin{array}{l}\text { Administrative } \\
\text { Procedures }\end{array}$ & \multicolumn{2}{|r|}{$r_{\mathrm{m}}$} & \multicolumn{2}{|c|}{-} \\
\hline & & Warming & \multicolumn{2}{|r|}{${ }^{\circ} \mathrm{m}$} & \multicolumn{2}{|c|}{-} \\
\hline & & $\begin{array}{c}\text { General Physical } \\
\text { Preparation } \\
\end{array}$ & \multicolumn{2}{|c|}{$1 \cdot \mathrm{m}$} & \multicolumn{2}{|c|}{ ( $3: 4)$ Game } \\
\hline & & $\begin{array}{l}\text { Private physical } \\
\text { preparation }\end{array}$ & \multicolumn{2}{|r|}{${ }^{\circ} \mathrm{m}$} & \multicolumn{2}{|c|}{$(2: 3)$ Game } \\
\hline \multicolumn{2}{|c|}{ The main part } & Small games & \multicolumn{2}{|c|}{$r \cdot m$} & \multicolumn{2}{|c|}{ ( $3: 4)$ Game } \\
\hline \multicolumn{2}{|c|}{ Closing part } & $\begin{array}{l}\text { Calm down } \\
\text { relaxation } \\
\end{array}$ & \multicolumn{2}{|r|}{$r \mathrm{~m}$} & \multicolumn{2}{|c|}{ - } \\
\hline \multicolumn{7}{|c|}{$\begin{array}{l}\text { Table (2) shows the } \\
\text { time distribution of the unit } \\
\text { and the average number of } \\
\text { games per part according to }\end{array}$} \\
\hline \multicolumn{7}{|c|}{$\begin{array}{l}\text { The arithmetic mean and standard deviation of both anxiety and } \\
\text { self-concept and psychological compatibility of the sample in } \\
\text { question }(\mathrm{N}=15)\end{array}$} \\
\hline \multirow{2}{*}{\multicolumn{3}{|c|}{ Variables }} & Pre m & asure & \multicolumn{2}{|c|}{ Post measure } \\
\hline & & & M & $\mathbf{E}$ & $\mathbf{M}$ & $\mathbf{E}$ \\
\hline \multicolumn{3}{|c|}{ Anxiety Scale } & 135.40 & 3.14 & 99.73 & 3.41 \\
\hline \multicolumn{3}{|c|}{ Self-concept scale for children } & 38.53 & 3.72 & 51.33 & 6.56 \\
\hline \multirow{5}{*}{ 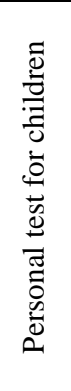 } & \multirow{5}{*}{ 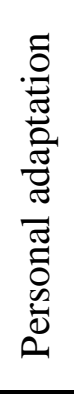 } & Adopt the child himself & 4.93 & 0.80 & 6.46 & 0.74 \\
\hline & & The child's sense of value & 4.60 & 1.35 & 6.40 & 0.63 \\
\hline & & The child feels free & 4.53 & 1.60 & 6.53 & 0.64 \\
\hline & & $\begin{array}{l}\text { The child's sense of } \\
\text { belonging }\end{array}$ & 4.73 & 1.33 & 6.27 & 0.88 \\
\hline & & $\begin{array}{l}\text { Freedom from the } \\
\text { tendency to be alone }\end{array}$ & 5.20 & 1.42 & 6.07 & 1.28 \\
\hline
\end{tabular}


Follow Table (3)

The arithmetic mean and standard deviation of both anxiety and self-concept and psychological compatibility of the sample in question $(\mathbf{N}=15)$

\begin{tabular}{|c|c|c|c|c|c|}
\hline & \multirow{2}{*}{ Variables } & \multicolumn{2}{|c|}{ Pre measure } & \multicolumn{2}{|c|}{ Post measure } \\
\hline & & $\mathbf{M}$ & $\mathbf{E}$ & $\mathbf{M}$ & $\mathbf{E}$ \\
\hline & Free of neurotic symptoms & 5.07 & 1.10 & 6.60 & 0.74 \\
\hline & Total score & 29.06 & 4.40 & 38.33 & 2.23 \\
\hline \multirow{7}{*}{ 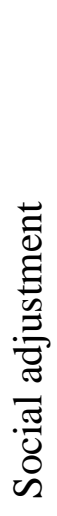 } & Social levels & 6.00 & 0.85 & 7.07 & 0.80 \\
\hline & social skills & 5.53 & 1.25 & 6.33 & 0.82 \\
\hline & $\begin{array}{l}\text { Freedom from anti- } \\
\text { social tendencies }\end{array}$ & 5.40 & 0.83 & 6.27 & 0.59 \\
\hline & Relationships in the family & 5.53 & 0.92 & 6.20 & 0.86 \\
\hline & Relationships in school & 5.53 & 0.99 & 6.92 & 0.70 \\
\hline & $\begin{array}{l}\text { Relationships in the local } \\
\text { environment }\end{array}$ & 5.60 & 1.12 & 7.40 & 1.06 \\
\hline & Total score & 33.59 & 2.61 & 40.19 & 2.40 \\
\hline \multicolumn{2}{|c|}{ The total score of the test } & 62.65 & 5.02 & 78.52 & 3.58 \\
\hline
\end{tabular}

Table (4)

Indications of differences between the average of the tribal and the remote for the sample under consideration in anxiety $(n=15)$

\begin{tabular}{c|c|c|c|c|c}
\hline \hline $\begin{array}{c}\text { In a } \\
\text { direction }\end{array}$ & $\begin{array}{c}\text { Statistical } \\
\text { significance }\end{array}$ & $\begin{array}{c}\text { Calculated } \\
\text { value (t) }\end{array}$ & $\begin{array}{c}\text { Square } \\
\text { deviations } \\
\text { of } \\
\text { differences }\end{array}$ & $\begin{array}{c}\text { Average } \\
\text { differences }\end{array}$ & $\begin{array}{c}\text { Total } \\
\text { differences }\end{array}$ \\
\hline \hline $\begin{array}{c}\text { Post } \\
\text { measure }\end{array}$ & Indicated & 27.82 & 345.33 & 35.67 & 535.00 \\
\hline \hline
\end{tabular}

The value of (t) tabular at the degree of freedom (14) and the level of significance $(0.05)=1.761$

Table (4) shows the between the mean and following: remote measurements of the 1-There are statistically sample under consideration significant differences in anxiety and in the 


direction of $\begin{array}{lll}\text { post- } & \text { measurement } & \text { indicates } \\ \text { measurement } \quad \text { (where the } & \text { improvement) }\end{array}$
low level of anxiety in post-

\section{Table (5)}

Indications of differences between the average of the tribal and the post

For the sample under consideration in the self-concept $(n=15)$

\begin{tabular}{l|l|l|l|l|l}
\hline \hline $\begin{array}{c}\text { In a } \\
\text { direction }\end{array}$ & $\begin{array}{c}\text { Statistical } \\
\text { significance }\end{array}$ & $\begin{array}{c}\text { Calculated } \\
\text { value (t) }\end{array}$ & $\begin{array}{c}\text { Square } \\
\text { deviations } \\
\text { of } \\
\text { differences }\end{array}$ & $\begin{array}{c}\text { Average } \\
\text { differences }\end{array}$ & $\begin{array}{c}\text { Total } \\
\text { differences }\end{array}$ \\
\hline \hline $\begin{array}{l}\text { Post } \\
\text { measure }\end{array}$ & Indicated & 6.58 & 794.65 & 12.80 & 192.00 \\
\hline \hline
\end{tabular}

The value of (t) tabular at the degree of freedom (14) and the level of significance $(0.05)=1.761$

\begin{tabular}{|c|c|c|}
\hline $\begin{array}{l}\text { Table }(5) \\
\text { following: }\end{array}$ & hows & $\begin{array}{l}\text { remote measurements of the } \\
\text { sample in question in the }\end{array}$ \\
\hline $\begin{array}{l}\text {-There are } \\
\text { significant }\end{array}$ & $\begin{array}{l}\text { statistically } \\
\text { differences }\end{array}$ & $\begin{array}{l}\text { concept of self and } \\
\text { direction of telemetry. }\end{array}$ \\
\hline
\end{tabular}

between the mean and

Table (6)

Indications of differences between the average of the tribal and the remote of the sample under consideration in psychological compatibility $N=15$

\begin{tabular}{|c|c|c|c|c|c|c|c|}
\hline $\begin{array}{c}\text { Key } \\
\text { dimensions }\end{array}$ & $\begin{array}{c}\text { Sub } \\
\text { dimensions }\end{array}$ & $\begin{array}{c}\text { Total } \\
\text { differences }\end{array}$ & $\begin{array}{c}\text { Average } \\
\text { differences }\end{array}$ & $\begin{array}{c}\text { Square } \\
\text { deviations } \\
\text { of } \\
\text { differences }\end{array}$ & $\begin{array}{c}\text { Calculated } \\
\text { value }(t)\end{array}$ & $\begin{array}{l}\text { Statistical } \\
\text { significance }\end{array}$ & $\begin{array}{c}\text { In a } \\
\text { direction }\end{array}$ \\
\hline \multirow{6}{*}{ 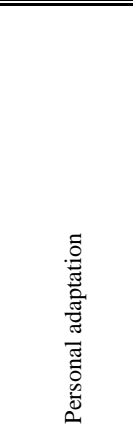 } & $\begin{array}{l}\begin{array}{l}\text { Adopt the } \\
\text { child himself }\end{array} \\
\end{array}$ & 23.00 & 1.53 & 15.73 & 5.59 & \multirow{6}{*}{ indicated } & \multirow{6}{*}{ Post measure } \\
\hline & $\begin{array}{l}\text { The child's } \\
\text { sense of value }\end{array}$ & 27.00 & 1.80 & 24.40 & 5.28 & & \\
\hline & $\begin{array}{l}\text { The child } \\
\text { feels free }\end{array}$ & 30.00 & 2.00 & 28.00 & 5.48 & & \\
\hline & $\begin{array}{l}\begin{array}{l}\text { The child's } \\
\text { sense } \\
\text { belonging }\end{array} \\
\end{array}$ & 23.00 & 1.53 & 27.73 & 4.21 & & \\
\hline & $\begin{array}{l}\text { Freedom from } \\
\text { the tendency } \\
\text { to be alone }\end{array}$ & 13.00 & 0.87 & 23.73 & 2.59 & & \\
\hline & $\begin{array}{l}\text { Free } \\
\text { neurotic } \\
\text { symptoms }\end{array}$ & 23.00 & 1.53 & 21.73 & 4.76 & & \\
\hline
\end{tabular}


Follow Table (6)

Indications of differences between the average of the tribal and the remote of the sample under consideration in psychological compatibility $N=15$

\begin{tabular}{|c|c|c|c|c|c|c|c|}
\hline $\begin{array}{c}\text { Key } \\
\text { dimensions }\end{array}$ & $\begin{array}{c}\text { Sub } \\
\text { dimensions }\end{array}$ & $\begin{array}{c}\text { Total } \\
\text { differences }\end{array}$ & $\begin{array}{c}\text { Average } \\
\text { differences }\end{array}$ & $\begin{array}{c}\text { Square } \\
\text { deviations } \\
\text { of } \\
\text { differences }\end{array}$ & $\begin{array}{c}\text { Calculated } \\
\text { value }(t)\end{array}$ & $\begin{array}{c}\text { Statistical } \\
\text { significance }\end{array}$ & $\begin{array}{c}\text { In a } \\
\text { direction }\end{array}$ \\
\hline & Total score & 139.00 & 9.26 & 256.93 & 8.37 & & \\
\hline \multirow{7}{*}{ 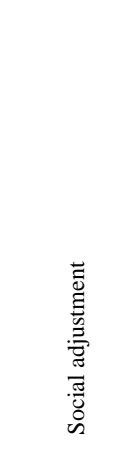 } & $\begin{array}{l}\text { Social } \\
\text { levels }\end{array}$ & 16.00 & 1.07 & 20.93 & 3.39 & & \\
\hline & social skills & 12.00 & 0.80 & 18.40 & 2.70 & & \\
\hline & $\begin{array}{l}\text { Freedom from } \\
\text { anti-social } \\
\text { tendencies }\end{array}$ & 13.00 & 0.86 & 5.73 & 5.21 & & \\
\hline & $\begin{array}{l}\text { Relationships } \\
\text { in the family }\end{array}$ & 10.00 & 0.67 & 17.33 & 2.33 & & \\
\hline & $\begin{array}{l}\text { Relationships } \\
\text { in school }\end{array}$ & 21.00 & 1.40 & 27.60 & 3.86 & & \\
\hline & $\begin{array}{l}\text { Relationships } \\
\text { in the local } \\
\text { environment }\end{array}$ & 27.00 & 1.80 & 16.40 & 6.44 & & \\
\hline & Total score & 99.00 & 6.60 & 161.60 & 7.52 & & \\
\hline \multicolumn{2}{|c|}{ The total score of the test } & 238.00 & 15.86 & 455.73 & 10.77 & & \\
\hline
\end{tabular}

The value of (t) tabular at the degree of freedom (14) and the level of significance $(0.05)=1.761$

Table (6) shows the following:

1-There are statistically significant differences between the mean and remote measurements of the sample under study in both:

personal and social adjustment dimensions, subdimensions of each, and the total score of the test and the direction of postmeasurement.

Table (7)

Percentage of rate of change in both anxiety and self - concept and psychological compatibility of the sample in question $(N=15)$

\begin{tabular}{|c|c|c|c|}
\hline Study variables & $\begin{array}{l}\text { Average tribal } \\
\text { measurement }\end{array}$ & $\begin{array}{l}\text { Average post } \\
\text { measurement }\end{array}$ & $\begin{array}{c}\text { Rate of } \\
\text { change\% }\end{array}$ \\
\hline Anxiety & 135.40 & 99.73 & 26.34 \\
\hline Self Concept & 38.53 & 51.33 & 33.22 \\
\hline \multicolumn{4}{|l|}{ Personal adaptation } \\
\hline $\begin{array}{l}\begin{array}{l}\text { Adoption } \\
\text { himself }\end{array} \\
\text { of the child } \\
\end{array}$ & 4.93 & 6.46 & 31.03 \\
\hline
\end{tabular}


Follow Table (7)

Percentage of rate of change in both anxiety and self - concept and psychological compatibility of the sample in question $(N=15)$

\begin{tabular}{|c|c|c|c|}
\hline Study variables & $\begin{array}{c}\text { Average tribal } \\
\text { measurement }\end{array}$ & $\begin{array}{l}\text { Average post } \\
\text { measurement }\end{array}$ & $\begin{array}{c}\text { Rate of } \\
\text { change\% }\end{array}$ \\
\hline The child's sense of value & 4.60 & 6.40 & 39.13 \\
\hline The child feels free & 4.53 & 6.53 & 44.15 \\
\hline $\begin{array}{l}\begin{array}{l}\text { The child's } \\
\text { belonging }\end{array} \\
\text { bense of } \\
\end{array}$ & 4.73 & 6.27 & 32.56 \\
\hline $\begin{array}{l}\text { Freedom from the } \\
\text { tendency to be alone }\end{array}$ & 5.20 & 6.07 & 16.73 \\
\hline $\begin{array}{ll}\begin{array}{l}\text { Free } \\
\text { symptoms }\end{array} & \text { neurotic } \\
\end{array}$ & 5.07 & 6.60 & 30.18 \\
\hline $\begin{array}{lll}\begin{array}{l}\text { Total } \\
\text { dimension }\end{array} & \text { degree } & \text { of } \\
\end{array}$ & 29.06 & 38.33 & 31.90 \\
\hline Social levels & 6.00 & 7.07 & 17.83 \\
\hline social skills & 5.53 & 6.33 & 14.47 \\
\hline $\begin{array}{l}\text { Freedom from anti- } \\
\text { social tendencies }\end{array}$ & 5.40 & 6.27 & 16.11 \\
\hline $\begin{array}{lll}\begin{array}{l}\text { Relationships } \\
\text { family }\end{array} & \text { in the } \\
\end{array}$ & 5.53 & 6.20 & 12.12 \\
\hline Relationships in school & 5.53 & 6.92 & 25.14 \\
\hline $\begin{array}{l}\text { Relationships in the } \\
\text { local environment }\end{array}$ & 5.60 & 7.40 & 32.14 \\
\hline $\begin{array}{l}\text { Total degree of } \\
\text { dimension }\end{array}$ & 33.59 & 40.19 & 19.65 \\
\hline $\begin{array}{l}\text { The total score of } \\
\text { the test }\end{array}$ & 62.65 & 78.52 & 25.33 \\
\hline
\end{tabular}

\section{Table (7) shows the following:}

- The rates of change in the main psychological variables were anxiety, self concept, psychological compatibility as a whole between $25.33 \%$ and $33.33 \%$. The concept of self achieved the highest rate of $33.22 \%$, followed by anxiety at $26.34 \%$ As a whole by $25.33 \%$. -The rates of change of axes for dimensions to personal adaptation ranged from $16.73 \%$ to $14.4 \%$, while the change rate for the dimension as a whole was $31.9 \%$.

- The rates of change of the sub-axes of the social adjustment dimension ranged from $12.12 \%$ to $32.14 \%$, while the change rate for the dimension as a whole was $19.65 \%$ 
Interpretation

discussion of results:

It is clear from the results of the research (Table 3 ) that there are statistically significant differences between the average of the tribal and remote measurements of the sample of anxiety research and in the direction of telemetry.

The results indicated that there were differences in the degree of anxiety before and after the application of the program and in the direction of telemetry.

Despite the importance of the family in raising and nurturing the child properly, the family may face difficult social and social conditions that are not suitable for the healthy development of the child's character, such as the breakdown and disintegration of the family, as in divorce cases, the father's marriage without the mother, The family is subject to father's illness or imprisonment or to the death of the father or mother or both. All this leads to the existence of children without families and homeless people who lack care, care, affection and affection, and the child's feeling that he does not belong to a real family affects his psychological development and social cohesion and raises his concern and leads to a general disorder in his personality $(1: 48)$

And that deprivation of parental care is the first cause of the child's personality disorder. The deprivation of the mother is one of the most dangerous factors for the child's life and has serious and far-reaching effects on his personality for the rest of his future life, and the denial of the father does not have a model for depriving him of the jam he gives The lessons of life or the host that gives it its causes, and this in turn affects the acquisition of new negative behavior in the child such as aggression and dependence for this, the deprivation of the father is one of the most difficult circumstances that can have a harmful impact on the personality of children. (29: 162-164) (7:56(

The results of the studies of the "Engineer" (2001), "Amal Fahmy" (2001) and the " 2006), which indicated the positive impact of group activities, guidance and behavior to reduce the anxiety 
of students in the research sample.

The results of Table (4) indicate that there are statistically significant differences between the mean and remote measurements of the research sample in the concept of self and in the direction of telemetry, and the researcher attributed that result to the proposed program of the small games of knowledge, including the various activities contributed positively to changing the concept of the child For himself and provided him with many opportunities for self-development through the sense of success, and the sense of self-value through winning positions, which contributed to increase the sense of self and strengthen the experience of sports.

The child's sense of satisfaction and happiness as a result of the exercise of the activities included in the program contributed to the development of the positive concept of self and that the self grows as an integrated concept is subject to constant change as a result of the individual exposure to different positions and experiences, especially if these attitudes and experiences occur during the positive activity beloved to the individual who exercises it.

The study by Covel and McCleod confirms that one or both parents are less selfconfident, unable to maintain personal and social cohesion and are more prone to introversion, anxiety and depression. (30:25)

The results of the studies confirmed that the effectiveness of Heimberg et coll, as in the case of long-term study, showed the superiority and effectiveness of cognitivebehavioral therapy in comparison with the treatment of dementia. The improvement rate $(75 \%)$ was in cognitive therapy, (40\%). In the long run, the results remained in favor of cognitive behavioral therapy even after 4-6 years. (31: 294)

The various activities within the cognitive-behavioral program included in the program of collective and individual counseling sessions in the positions within the program and contributed to provide many opportunities for the development of the selfconcept of students as exposure to the positions of experience 
supports the positive concept of self, and the results of several studies showed that the exercise of sports activities Positive impact on the development of the concept of self and the result is consistent with the results of the study Amal Fahmy "(2006), which indicated the positive impact of the practice of activities within the guidance programs on the self-concept of the research sample.

On the other hand, the results of Table (5) indicated that there are statistically significant differences between the average of the tribal and the remote measurements of the sample of the research in psychological compatibility, both personal and social, and in the direction of postmeasurement. The researcher attributed this result to the proposed program, Opportunities to improve personal and social adjustment through a sense of success, cooperation with peers and competition.

The proposed sports program using small games, including various activities, has contributed positively to achieving personal adjustment and helped in self-reliance. Participation in competitions promotes the child's selfreliance and sense of selfworth, the child's sense of belonging to the group in which he belongs, To make the effort to win he and his team and this makes the child free from the love of self and selfish, but focuses all his interest on winning he and the group against him against the other group, and thus make the child feel good about himself but open to the community and be more positive And the community around it.

On the other hand, the results of the research showed an increase in the social skills in the research sample through participation in the collective groups included in the program as well as activities which contributed positively to the development of the spirit of cooperation, participation and happiness of others. And the community around him, such as family and school and relations with the environment around him, which in turn reflected on improving his psychological compatibility.

The results of Table (7) showed the difference in the 
rate of change in psychological aspects. The self concept achieved the highest rate of change $(33.22 \%)$, followed by anxiety (26.34\%), psychological compatibility $(25.33 \%)$

In light of this finding, the researcher believes that it is important to help children to get rid of anxiety and increase their psychological compatibility by providing educational and guidance programs that contribute to strengthening their self-concept and integrating them with the social environment in which they live.

\section{Conclusions}

-The proposed program using small games has led to an improvement in self-concept among children with fractured families.

Y-The proposed program, using small games, has reduced the level of anxiety among children with fractured families.

-The proposed program using small games has led to an improvement in the level of personality of children with fractured families.

\section{Recommendations:}

-Use of the proposed program using small games because of the improvement in the level of psychological variables in children with fractured families.
-Working to pay attention to the psychological care of children from the early stages of family separation.

-Improve children's mental health care through schools.

-Improve the level of psychological care for children through the role of social workers in schools.

-The need to conduct similar studies in different stages of the Sunni and provide solutions to them.

\section{References}

1-Adel Mohammed (2000): Behavioral Cognitive Therapy, Foundations and Applications, Dar Al-Rashad, Cairo.

\section{2- Ahmed Abdul Azim}

Abdullah (2002): "The effect of the program of motor education using small recreational games on some variables kinetic and motor satisfaction of children (6-9) years, $\mathrm{PhD}$ thesis, unpublished, Faculty of Physical Education, Mansoura University.

\section{3-Amani} Mohamed

Mohamed: "The effect of recreational program for athletes of withdrawal behavior on self-efficacy among students of the first episode of basic education" $\mathrm{PhD}$ thesis, unpublished, Faculty of Physical Education, Tanta University, 2000. 
4-Amr Ahmed Mohamed Ibrahim (1997): Behavioral problems of students deprived of their families and the role of service of the individual in the face, Journal of the constraints of childhood, No. 6, May 225: 301.

5-Aziza Mahmoud Salem, Hwaida Fathy El Sayed, Madiha Mahmoud AbdelQani: The effect of a proposed program for educational games on some physical variables and the level of performance of some skills of ground movements in gymnastics and psychological compatibility of deaf deaf students, published scientific research, Journal of Mathematical Science and Arts, Faculty of Physical Education For Girls, Helwan University, 2005.

6-Cottraux J (2001) Les thérapies comportementales et cognitives, Masson, Paris.

7- Fatima Hamad Mujahid (2005): Effectiveness of a pilot program to reduce anxiety in a sample of children residing in the shelter institution, published in the conference "Technology Education in the Knowledge Society from 3 to 4 May 2005.
8-Jamal Shehata Habib

(1999): psychological and social risks to children of housing institutions and the role of social service in the face of them, the conference of the Egyptian child between danger and addiction, Faculty of Social Work, Helwan University.

\section{9- Hassan Mustafa Abdul} Muti (2004): the climate of the family and the personality of children, I 1 Cairo: Dar Sahab. 10-Huda Mohammed Qenaoui (1993): the child and its origin and needs, Cairo, the AngloEgyptian Library.

11-Iman Rifaat Al-Saeed: A proposed recreational program for the development of some physical characteristics of sport gymnastics and its relation to the level of motor performance, published scientific research, Journal of Physical Education and Mathematical Sciences, Faculty of Physical Education, Helwan University, 2013.

12-Issa Abdullah Jaber (1999): A field study to build a program for the treatment of children who are behavioral disorders by play, unpublished doctoral thesis, Institute of Graduate Studies for Children, Ain Shams University. 
13- Kamelia Abdel- Fattah (1999), collective psychotherapy for children using toys, i 3, the Egyptian Renaissance Library, Cairo.

\section{4-Laila}

Marzouq

Al-

Mazroui (2003): Effectiveness of an orientation program for the development of social skills in alleviating the sense of psychological loneliness among a sample of female students at Umm Al-Qura University. Issue 6

15-Lili Abdel Hamid (2006) Methods of care provided to the children of S.O. Children of shelter institutions and their relationship to some aspects of the personality of these children, Journal of Child Obstacles, No. 15 May.

16-Marsa Kamal Ibrahim (2008): family and family consensus, Cairo, publishing house for universities.

17-Mansour, Abdul Majid Sayed Ahmed (2000): Family Care and Parental Trends between Acceptance, Refusal and Denial of Special Needs, Proceedings of the Second International Conference on Disability and Rehabilitation, $126-167$

18-Mustafa

Al-Harouny

(2005): The Effectiveness of a
Mentoring Program in Reducing the Psychological Stress of the Orphan Students and its Impact on the Methods of Recollection and Achievement of the Study, Research published in the Journal of the Faculty of Education in Banha, Volume 15, Number 62.

19-Nabil Abdel Fattah Hafez et al. (2001): Introduction to Social Psychology, Cairo, Library of the East.

20-Najdi and Nais Habashi (1996): A Study of Some Psychological Aspects of Orphans and Ordinary Children in the First Seminar of Basic Education Journal of Research in Education and Psychology. Volume 4, April 1, Faculty of Education, Minia University.

21-- Nowak- Fabrykowski,Krystyna. (2004): Care and education of orphaned children in poland Journal, Vol. 174 (78) 621-627.

22-Osama Kamel Rateb (1999): "motor development, the entrance to the integrated development of children and adolescents, the Arab Thought House, Cairo.

23-Peter H. Wollf \&
Geberemeskel
:(1998): Orphanages Part of 
The Problem or Part of The Soultion . Boston, The American Journal of Psychiatry , vol 155

24-Qutaiba Chalabi, Fahad Al-Yahya (1996)

Psychotherapy and its applications in the Arab society, Media Company for Printing and Publishing, Riyadh.

25-Sami Mohammed Zidan (2000): Self-efficacy and the role of sex in orphans and ordinary students in late childhood, Master's thesis Faculty of Education, Mansoura University.

26- Sawsan Mohammed AlGhazali (2001): Principles of Public Health and Preventive, Social and Behavioral Medicine, Faculty of Education, Ain Shams University.

27- Shaheen Mohamed Mustafa (2011): The relationship between the practice of cognitive behavioral therapy in the service of the individual and the development of social competence of orphan children, published research, the 24th International Scientific Conference of Social Service.

\section{8-Suheir}

Muhammad

Salama Shash (2002): Special education for the mentally disabled between isolation and integration, library. Zahraa AlSharq, Egypt, p

29-Taanila , A.L.,et al.(2001): Coping of parents with disabled children. Child :care. Health\&development. vol.28, Issue 1: 73-86

30- Wolfgan, M. et al. (2002): Social of crinie and deling vency, N.Y. Johnwiely p. 338

\section{1- Veronica Kolsheed} (2000): Introduction to the practice of social service, translation Hamdi Mansour and Said Aweida, Alexandria, the scientific office for computer, publishing and distribution.

32- Zainab Mahmoud Shoukair (1999): Effect of early parental deprivation on adaptive behavior and nonadaptive behavior of children in adolescence, Journal of the Faculty of Education in Banha, January 44-86. 